\title{
Journal of Threatened Taxa
}

Building evidence for conservation globally

www.threatenedtaxa.org

ISSN 0974-7907 (Online) | ISSN 0974-7893 (Print)

\section{COMMUNICATION}

\section{ECOLOGICAL NICHE MODELLING PREDICTS SIGNIFICANT IMPACTS OF FUTURE CLIMATE CHANGE ON TWO ENDEMIC RODENTS IN EASTERN AFRICA}

Aditya Srinivasulu, Alembrhan Assefa \& Chelmala Srinivasulu

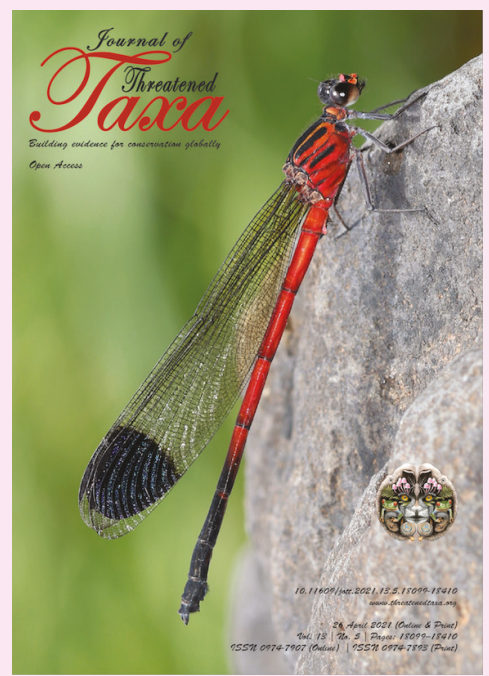

26 April 2021 | Vol. 13 | No. 5 | Pages: 18164-18176

DOI: $10.11609 /$ jott.6715.13.5.18164-18176

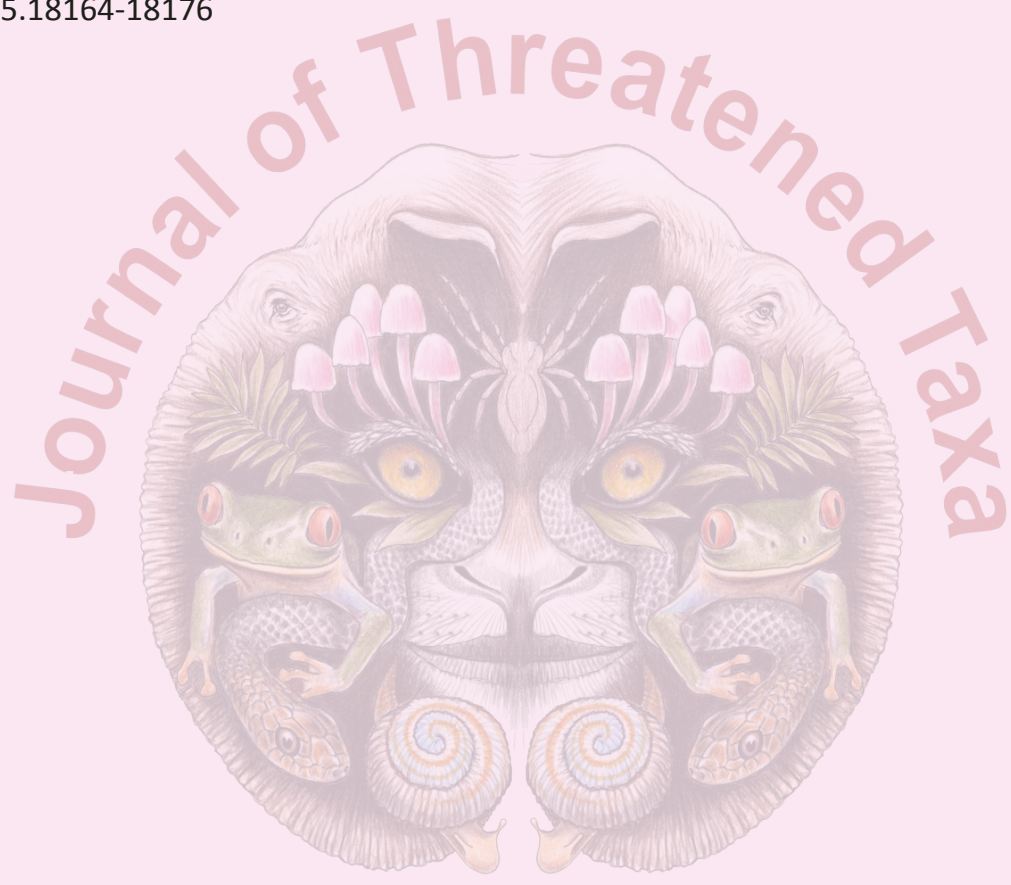

For Focus, Scope, Aims, and Policies, visit https://threatenedtaxa.org/index.php/JoTT/aims_scope

For Article Submission Guidelines, visit https://threatenedtaxa.org/index.php/JoTT/about/submissions

For Policies against Scientific Misconduct, visit https://threatenedtaxa.org/index.php/JoTT/policies_various

For reprints, contact <ravi@threatenedtaxa.org>

The opinions expressed by the authors do not reflect the views of the Journal of Threatened Taxa, Wildlife Information Liaison Development Society, Zoo Outreach Organization, or any of the partners. The journal, the publisher, the host, and the partners are not responsible for the accuracy of the political boundaries shown in the maps by the authors.

Publisher \& Host

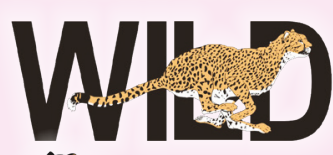

Member

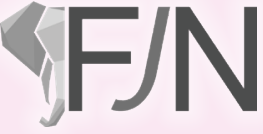

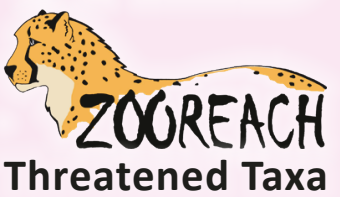




\title{
Ecological niche modelling predicts significant impacts of future climate change on two endemic rodents in eastern Africa
}

\author{
Aditya Srinivasulu ${ }^{1}$ (D), Alembrhan Assefa ${ }^{2}$ (i) \& Chelmala Srinivasulu ${ }^{3}$ (i) \\ ${ }^{1}$ Wildlife Information and Liaison Development (WILD) Society, No. 12, Thiruvannamalai Nagar, Saravanampatti - Kalapatti Road, \\ Saravanampatti, Coimbatore, Tamil Nadu 641035, India. \\ ${ }^{2}$ Department of Biology, College of Natural and Computational Science, Adigrat University, P.O. Box: 50, Adigrat, Ethiopia. \\ ${ }^{2,3}$ Natural History Museum \& Wildlife Biology and Taxonomy Lab, Department of Zoology, University College of Science, \\ Osmania University, Hyderabad, Telangana 500007, India. \\ ${ }^{3}$ Centre for Biodiversity and Conservation Studies, \#F6 CFRD Building, Osmania University, Hyderabad, Telangana 500007, India. \\ ${ }^{3}$ Systematics, Ecology \& Conservation Laboratory, Zoo Outreach Organization, 12 Thiruvannamalai Nagar, Saravanampatty, Coimbatore, \\ Tamil Nadu 641035, India. \\ 19a.chelmala1@gmail.com, ${ }^{2}$ assefaw12@gmail.com, ${ }^{3}$ chelmala.srinivasulu@osmania.ac.in (corresponding author)
}

\begin{abstract}
The impact of climate change on rodents is well studied, however, many of these studies are restricted to the Americas. Smallto medium-sized rodents, especially murids, are restricted in their home range and microclimatic niche breadth, and are known to be more sensitive to changes in bioclimatic conditions over time. We analyzed the effect of future climatic scenarios in the near and distant future, using two global climate models (CanESM5 and MIROC-ES2L) for two shared socio-economic pathways (SSP2-4.5 and SSP5-8.5), on two eastern Africa endemic small-bodied mice: Stenocephalemys albipes and Mastomys awashensis. Our results indicate that while $S$. albipes showed increases in area of climatic suitability in the future, $M$. awashensis is predicted to suffer severe decline in the area of its fundamental niche.
\end{abstract}

Keywords: Awash Multimammate Mouse, Ethiopian White-footed Mouse, decline, microclimate, MaxEnt.

Citation: Srinivasulu, A., A. Assefa \& C. Srinivasulu (2021). Ecological niche modelling predicts significant impacts of future climate change on two endemic rodents in eastern Africa. Journal of Threatened Taxa 13(5): 18164-18176. https://doi.org/10.11609/jott.6715.13.5.18164-18176

Copyright: (C) Srinivasulu et al. 2021. Creative Commons Attribution 4.0 International License. JoTT allows unrestricted use, reproduction, and distribution of this article in any medium by providing adequate credit to the author(s) and the source of publication.

Funding: The major funding for carrying out this research was granted by the Government of Ethiopia and Adigrat University, Ethiopia.

Competing interests: The authors declare no competing interests.

Author details: ADITYA SRINIVASULU is an independent researcher associated with the Wildlife Information and Liaison Development (WILD) Society, India, and is working on the application and integration of modern techniques with systematics, biogeography, and conservation biology of South Asian tetrapods. ALEMBRHAN ASSEFA was PhD student at Department of Zoology, Osmania University, India and worked on diversity and ecology of small mammals in Kafta-Sheraro National Park, Tigray region, Ethiopia. He is currently working in Department of Biology, Adigrat University, Ethiopia. CHELMALA SRINIVASULU is the head of Wildlife Biology and Taxonomy Laboratory, Department of Zoology, Osmania University, India and is working on diversity and taxonomy of vertebrates in South Asia.

Author contribution: All authors contributed equally to the study, analysis, and writing the manuscript.

Acknowledgements: We thank the head, Department of Zoology, Osmania University, India and head, Department of Biology, Adigrat University, Ethiopia for the facilities, and the Ethiopian Government for Research Fellowship to AA.
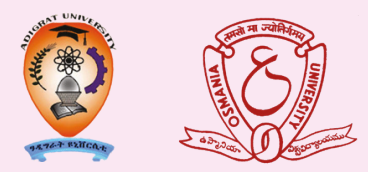


\section{INTRODUCTION}

Rodents are the most diverse and abundant groups of mammals, accounting for approximately 2,200 species (Monadjem et al. 2015), distributed across the world on every continent except Antarctica (Nowak 1999). They occur in a wide range of terrestrial habitats, and serve the purpose of ecosystem engineers (Zhang et al. 2003) and keystone species in an ecosystem. Africa supports a large diversity of rodent species, with at least 463 known species (Monadjem et al. 2015), and new species described regularly; however, the ranges and habitats of some rodent species in Africa are not clearly known, due to many reasons ranging from inaccessible localities to insufficient data or resources (Kingdon 1997; Habtamu \& Bekele 2008; Takele et al. 2011). This is of especial concern as rodents are not only diverse, but are an integral part of the ecosystem's functioning and health, contributing essential services (Fischer 2017). They are also of biogeographic, systematic, and conservation interest and priority (Happold 2013; Monadjem et al. 2015).

Rodents distributed in xerothermic habitats have been known to benefit from climate change towards a warmer, drier climate scenario, most likely due to their thermo-xerophilia being supported by the climatic conditions (Cameron \& Scheel 2001). Climate change towards warmer and drier conditions has also resulted in an increase in species diversity in rodents in warm regions (Szpunar 2008). It is also possible that due to the effect of changing climate scenarios, migrations and emigrations take place, resulting in new regional populations being seeded and established in order to occupy the fundamental niche (Royer et al. 2016). As an extension of the conclusions drawn by Millien \& Damuth (2004), treating fragmented populations as islands, it may be inferred that there is a possible slowing of the evolutionary rate of rodents as a result of climate change.

Hutchinson (1957) proposed the concept of the 'ecological niche' - an abstract representation of the biotic and abiotic factors deciding and limiting the distribution and abundance of a species. Identifying the ideal environmental niche of a species by accounting for certain limiting factors is one of the aims of ecological niche modelling (ENM) - this ideal niche is referred to as the fundamental niche (Griesemer 1994). The fundamental niche does not represent the real distribution of the species; in fact, it is usually larger than the realised distribution of the species (Soberón \& Arroyo-Peña 2017). Ecological niche modelling uses

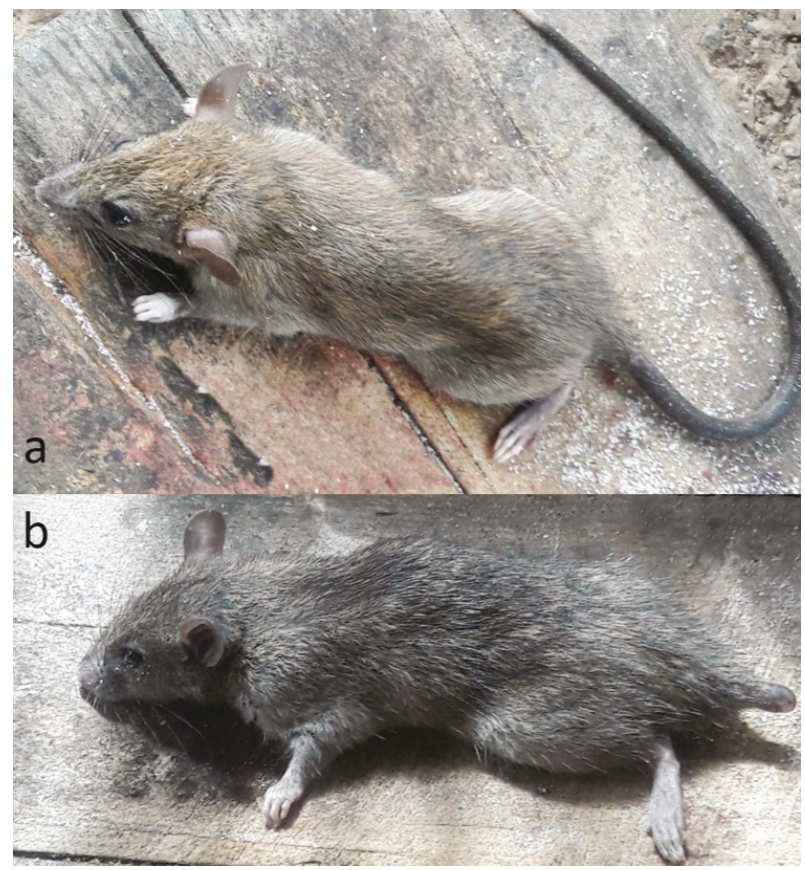

Image 1. a.-Ethiopian White-footed Mouse Stenocephalemys albipes (Rüppell, 1842) | b-Awash Multimammate Mouse Mastomys awashensis (Lavrenchenko et al. 1998). (C) Alembrhan Assefa.

presence-only or presence-absence occurrence data of a species and analyses it against a set of spatial covariates-most often, bioclimatic variables are used as the covariates in a climate change ENM study. Many diverse algorithms may be used for ENM, including generalised linear models (GLM), multivariate adaptive regression splines (MARS), and random forests (RF). MaxEnt (Phillips et al. 2006), however, is by far the most widely used algorithm due to its use of presence-only data, ease of access, customizability, and robustness (Ortega-Huerta \& Peterson 2008; Elith et al. 2011; Merow et al. 2013; Radosavljevic \& Anderson 2014).

The present study analyses the effect of current and future climate scenarios on the predicted fundamental niche of two Ethiopian-endemic rodents, the Awash Multimammate Mouse Mastomys awashensis (Lavrenchenko et al. 1998) and the Ethiopian Whitefooted Mouse Stenocephalemys albipes (Rüppell, 1842) (Image 1). It aims to predict the impact of future climate change pathways (SSP2-4.5 and SSP5-8.5) on the niches of these species using maximum entropy (MaxEnt) modelling. 


\section{MATERIALS AND METHODS}

\section{Study area}

This study is based in Ethiopia and Eritrea, as both Mastomys awashensis and Stenocephalemys albipes are endemic to this region (Image 2). M. awashenis is distributed in the scrublands of the Awash River bank, which primarily comprises small Acacia and Commiphora trees and thorny scrubs, and is also found in agricultural fields and wild areas of the northern highlands (Lavrenchenko et al. 1998; Meheretu et al. 2014). S. albipes occur in moist montane forests, scrublands at high altitudes, and agricultural fields (Yalden \& Largen 1992; Tilaye 2005; Kassa \& Bekele 2008) (Image 2). The study region varies widely in altitude, geography, and climatic conditions, resulting in a high diversity of biological resources and high levels of endemism. The altitude of the region varies from $115 \mathrm{~m}$ below sea level to $4,620 \mathrm{~m}$ above sea level, and it can be classified into three climatic zones - tropical, subtropical, and cool. The mean annual temperature ranges $16-27^{\circ} \mathrm{C}$, and the annual precipitation ranges $510-1,280 \mathrm{~mm}$. While the study is restricted to Ethiopia and Eritrea, the ecological niche modelling (ENM) was conducted on the entirety of continental Africa to account for ecological niche data outside the political borders of these countries; final models were then cropped to Ethiopia and Eritrea's national boundaries.

\section{Data collection}

Occurrence data of the two study species were collected from Ethiopia and border regions in Eritrea. A total of 101 presence records were collected (34 for M. awashensis and 67 for S. albipes) from published literature (Lavrenchenko et al. 1998; Habtamu \& Bekele 2008; Colangelo et al. 2010; Assefa \& Srinivasulu 2019) and from GBIF (accessed August 2020) (Image 2; Appendix 1). Occurrence data of each species were spatially thinned using the package spThin (AielloLammens et al. 2015) in $\mathrm{R}$ such that points within a $2 \mathrm{~km}^{2}$ area of each other were treated as duplicates and removed to account for spatial bias and autocorrelation

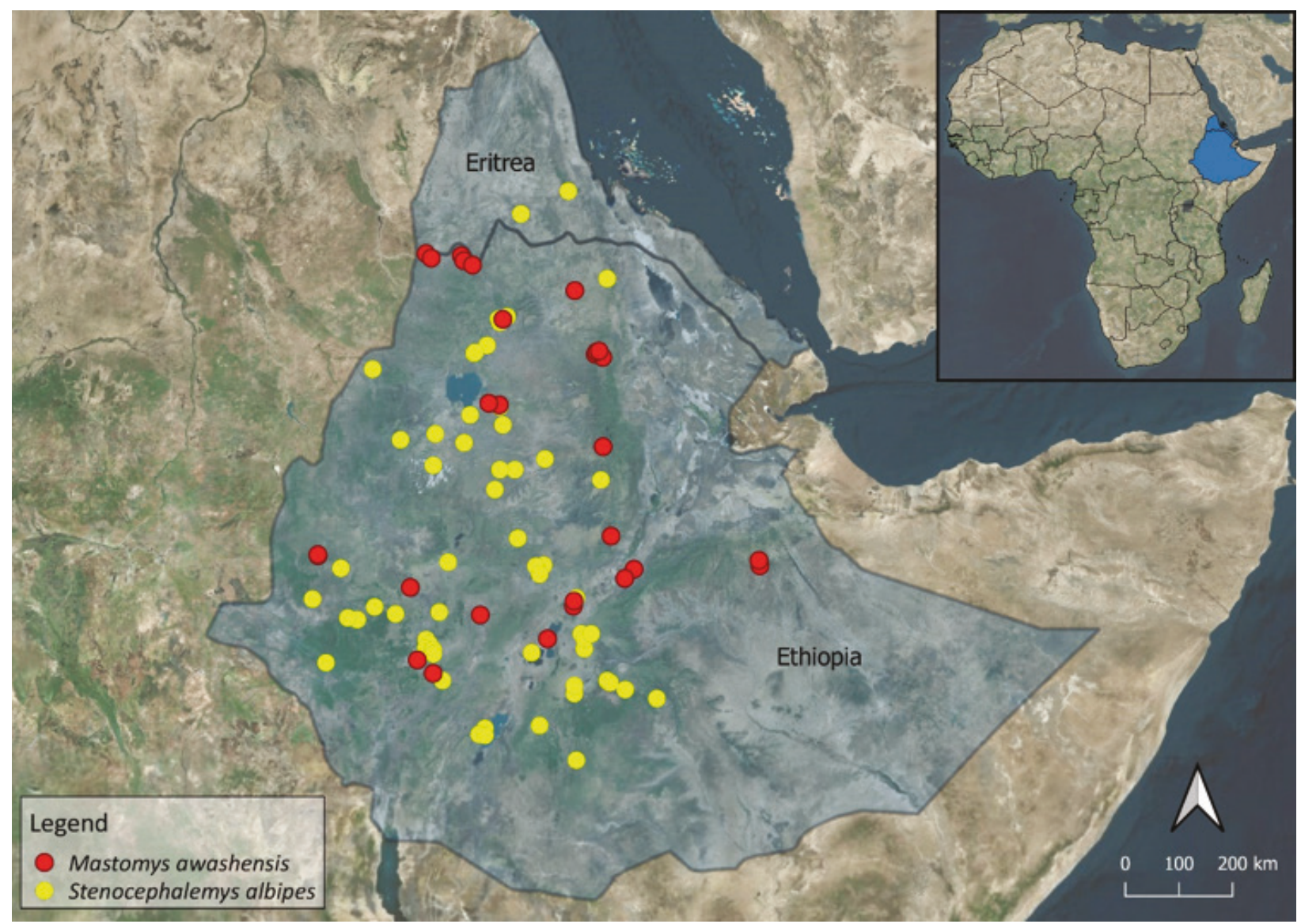

Image 2. Satellite map of the study area, with occurrence localities (before spatial rarefaction) shown (inset - satellite map of continental Africa, with study area highlighted in blue). 
in sample collection.

Nineteen bioclimatic environmental variables were acquired at a resolution of 2.5 arc-minutes from the Worldclim 2 database for the current time period (Fick \& Hijmans 2017). For future scenarios, 2.5 arcminute resolution data from the Coupled Model Intercomparison Project 6 (CMIP6) were acquired for two shared socioeconomic pathways - SSP2 representing a middle-of-the-road scenario (Fricko et al. 2017) and SSP5 representing fossil-fuelled development in the future (Kriegler et al. 2017). Two global climate models were used to account for inter-model disparities in projection (Porfirio et al. 2014) - MIROC-ES2L (Tachiiri et al. 2019a,b) and CanESM5 (Swart et al. 2019a,b). Data were acquired for the 2041-2060 (near future) and 2061-2080 (distant future) time periods.

An analysis of multicollinearity conducted using the package Virtualspecies (Leroy et al. 2015) in $R$ version 4.0.2 (R Core Team 2020) was used to select relatively uncorrelated variables for the modelling. Variables with an absolute value of Pearson's $r>0.75$ were subjected to pairwise comparisons of perceived ecological importance based on our understanding of the ecology and biology of the two species. All climate data were initially cropped to the extent of continental Africa; islands surrounding Africa including Madagascar were included, but southern Europe, the Middle East, and the Arabian Peninsula were not used.

\section{Ecological niche modelling}

A presence-only approach was used to model species distributions, using MaxEnt version 3.4.1 (Phillips et al. 2006); however, careful consideration of biases and selection of parameters is an essential step in order to maximise the robustness and reliability of niche models generated using MaxEnt (Derville et al. 2018). Hence, parameterisation was done according to the processes outlined in Merow et al. (2013) and Feng et al. (2019). To account for spatial bias, a Gaussian kernel density bias file of bandwidth 0.5 was created using the package SpatialEco (Evans 2020) in R, in order to weight the generation of background (pseudo absence) points for the analysis.

The model was parameterised for feature classes and regularisation multipliers using the package ENMEval (Muscarella et al. 2014). We tested a set of five regularisation multipliers: $0.5,1,2,3$, and 5 , and six feature classes: Linear, Linear+Quadratic, Hinge, Hinge+Quadratic, Linear+Quadratic+Product, and Hinge+Quadratic+Product. Five-fold cross-validation was used and model performance was assessed using the area under the receiver operating characteristic curve (AUC) and the true skill statistic (TSS).

The continuous models for each scenario and each time period, as output by MaxEnt, were reclassified according to the maximum test sensitivity+specificity (MSS) threshold into binary models - the positive cells represented the fundamental niche of the species for each scenario and time period according to bioclimatic data. Finally, the binary models were cropped to Ethiopia and Eritrea's national boundaries. Area of climatic suitability was calculated as a percentage based on the ratio of positive to zero cells in the final binary models.

\section{RESULTS}

\section{Ecological niche modelling}

For the modelling of both Mastomys awashensis and Stenocephalemys albipes, 12 bioclimatic layers were selected based on multicollinearity analysis (Appendix 2): BIO1 (Annual mean temperature), $\mathrm{BIO} 2$ (Mean diurnal range), BIO4 (Temperature seasonality), BIO5 (Maximum temperature of warmest month), BIO6 (Minimum temperature of coldest month), BIO8 (Mean temperature of wettest quarter), BIO9 (Mean temperature of driest quarter), BIO14 (Precipitation of driest month), BIO15 (Precipitation seasonality), BIO16 (Precipitation of wettest quarter), BIO18 (Precipitation of warmest quarter), and BIO19 (Precipitation of coldest quarter). After data cleaning and spatial thinning, 10 occurrence points were used for $M$. awashensis and 65 occurrence points were used for S. albipes. Models with the lowest $\triangle$ AICc values were selected as the final models for ENM analyses of each species - for $M$. awashensis this was Linear features with $\mathrm{RM}=0.5(\Delta$ $\mathrm{AICC}=0$ ), and for $S$. albipes this was Linear+Quadratic features with $\mathrm{RM}=0.5(\triangle \mathrm{AlCc}=0)$. The models for $M$. awashensis and S. albipes returned AUC values of 0.974 \pm 0.009 and $0.977 \pm 0.011$, respectively, and TSS values of 0.735 and 0.801 , indicating robust performance for both species. Mean diurnal range and temperature seasonality had high contribution to the models of both species (Table 1).

\section{Stenocephalemys albipes ENM}

The ecological niche model for S. albipes (MSS threshold 0.525 ) showed that $20.704 \%$ of the study area is climatically suitable in the current time period (Image 3; Table 2). In both future time periods, scenarios, and GCMs, there was significant increase, with an average increase of $18.437 \%$ to $39.141 \pm 3.695 \%$ in 2041-2060, 
Table 1. Variable contributions of each bioclimatic layer used in the analysis, for both species.

\begin{tabular}{|c|c|c|c|c|c|}
\hline \multirow[b]{2}{*}{ Variable } & \multirow[b]{2}{*}{ Name } & \multicolumn{2}{|c|}{ Percentage contribution } & \multicolumn{2}{|c|}{ Permutation importance } \\
\hline & & $\begin{array}{c}\text { Stenocephalemys } \\
\text { albipes }\end{array}$ & Mastomys awashensis & $\begin{array}{c}\text { Stenocephalemys } \\
\text { albipes }\end{array}$ & Mastomys awashensis \\
\hline $\mathrm{BIO1}$ & Annual mean temperature & 41.2 & 0 & 0 & 0 \\
\hline $\mathrm{BIO} 2$ & Mean diurnal range & 15.4 & 27.7 & 12.8 & 18.2 \\
\hline $\mathrm{BIO} 4$ & Temperature seasonality & 28 & 47.6 & 38.8 & 74.2 \\
\hline $\mathrm{BIO5}$ & Max temperature of warmest month & 0.1 & 0 & 0 & 0 \\
\hline $\mathrm{BIO6}$ & Min temperature of coldest month & 0.1 & 3.8 & 0.6 & 0.1 \\
\hline $\mathrm{BIO8}$ & $\begin{array}{l}\text { Mean temperature of wettest } \\
\text { quarter }\end{array}$ & 0.9 & 12.1 & 44.2 & 3 \\
\hline $\mathrm{BIO9}$ & Mean temperature of driest quarter & 2 & 0.2 & 0.4 & 0.5 \\
\hline $\mathrm{BIO14}$ & Precipitation of driest month & 0.5 & 1.9 & 0.4 & 2 \\
\hline $\mathrm{BIO15}$ & Precipitation seasonality & 0.6 & 1 & 1.4 & 0.9 \\
\hline $\mathrm{BIO} 16$ & Precipitation of wettest quarter & 0.5 & 0.6 & 0.6 & 0.6 \\
\hline $\mathrm{BIO18}$ & Precipitation of warmest quarter & 0.8 & 2.6 & 0.8 & 0.3 \\
\hline $\mathrm{BIO19}$ & Precipitation of coldest quarter & 9.9 & 2.4 & 0 & 0.1 \\
\hline
\end{tabular}

Table 2. Changes in climatically suitable areas of both species (in percentage values).

\begin{tabular}{|c|c|c|c|c|c|c|c|}
\hline \multicolumn{4}{|c|}{ Mastomys awashensis } & \multicolumn{4}{c|}{ Stenocephalemys albipes } \\
\hline Scenario & Time Period & CanESM5 & MIROC-ES2L & Scenario & Time Period & CanESM5 & MIROC-ES2L \\
\hline- & Current & \multicolumn{2}{|c|}{$46.077 \%$} & - & \multicolumn{2}{|c|}{ Current } & $20.704 \%$ \\
\hline SSP2-4.5 & $2041-2060$ & $0 \%$ & $0 \%$ & SSP2-4.5 & $2041-2060$ & 39.982 & 34.527 \\
\hline SSP2-4.5 & $2061-2080$ & $0 \%$ & $0 \%$ & SSP2-4.5 & $2061-2080$ & 40.113 & 35.353 \\
\hline SSP5-8.5 & $2041-2060$ & $0 \%$ & $0 \%$ & SSP5-8.5 & $2041-2060$ & 43.462 & 38.594 \\
\hline SSP5-8.5 & $2061-2080$ & $0 \%$ & $0 \%$ & SSP5-8.5 & $2061-2080$ & 47.407 & 39.186 \\
\hline
\end{tabular}

and a further increase of $1.373 \%$ to $40.514 \pm 5.035 \%$ in 2061-2080. There was little difference in the percentage area of future climatic suitability between SSP2-4.5 and SSP5-8.5 (Image 3; Table 2), indicating that different future climate scenarios have little impact on the overall effect of climate change on this species.

The variables with the highest percentage contribution and permutation importance for this species were temperature seasonality (BIO4; 28\% contribution, $38.8 \%$ p. imp.) and mean diurnal range (BIO2; $15.4 \%$ contribution, $12.8 \%$ p. imp.) (Table 1). Additionally, annual mean temperature (BIO1) had the highest percentage contribution to the model (41.2\%), but showed 0 permutation importance, and similarly, mean temperature of the wettest quarter $(\mathrm{BIO} 8)$ showed the highest permutation importance (44.2\%), but had a very low percentage contribution to the model (0.9\%).

In the current scenario, highest environmental suitability ( $>75 \%)$ according to climate was seen at a mean diurnal range $(\mathrm{BIO} 2)$ of $14.901 \pm 1.556{ }^{\circ} \mathrm{C}$, and a mean temperature seasonality (BIO4) of $114.903 \pm$ $28.698{ }^{\circ} \mathrm{C}$. In SSP2-4.5, representing a middle-of-theroad scenario, $\mathrm{BIO} 2$ underwent a slight decrease to a mean value of $14.137 \pm 1.139^{\circ} \mathrm{C}$ in the $2041-2060$ time period, and further to $14.065 \pm 1.185^{\circ} \mathrm{C}$ in 2061-2080; $\mathrm{BIO} 4$ also decreased to a mean value of $109.902 \pm 30.14$ ${ }^{\circ} \mathrm{C}$ in 2041-2060, and increased to $111.027 \pm 32.302$ ${ }^{\circ} \mathrm{C}$ in 2061-2080. In SSP5-8.5, representing a fossilfuelled economy, $\mathrm{BIO} 2$ underwent a decrease to a mean value of $14 \pm 1.171{ }^{\circ} \mathrm{C}$ in the 2041-2060 time period, and further to $13.572 \pm 1.258{ }^{\circ} \mathrm{C}$ in 2061-2080; BIO4, however, increased to a mean value of $116.249 \pm 33.281$ ${ }^{\circ} \mathrm{C}$ in 2041-2060, and further to $123.561 \pm 39.416{ }^{\circ} \mathrm{C}$ in 2061-2080 (Table 3).

\section{Mastomys awashensis ENM}

The ecological niche model for M. awashensis (MSS threshold 0.777 ) showed that $46.077 \%$ of the study area is climatically suitable in the current time period (Image 4; Table 2). In both future time periods, scenarios, and 

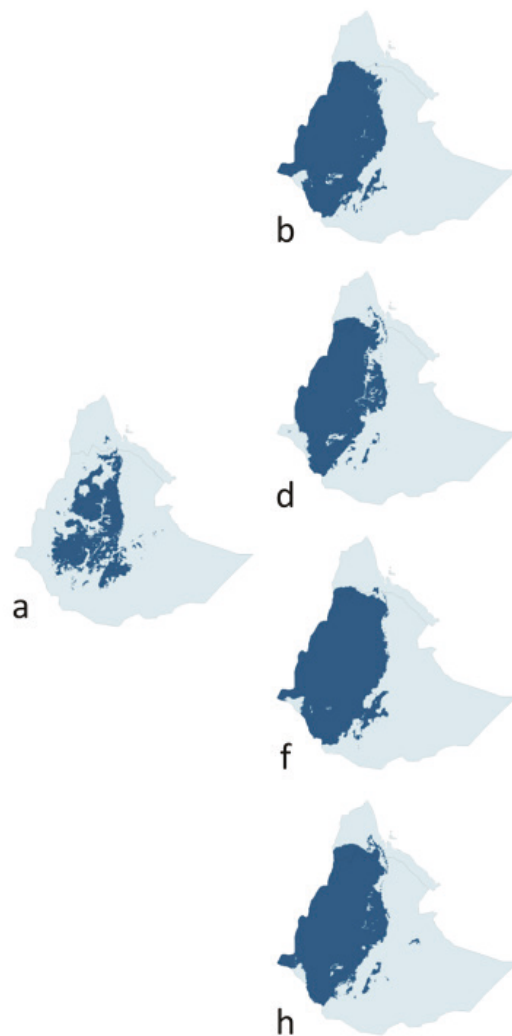
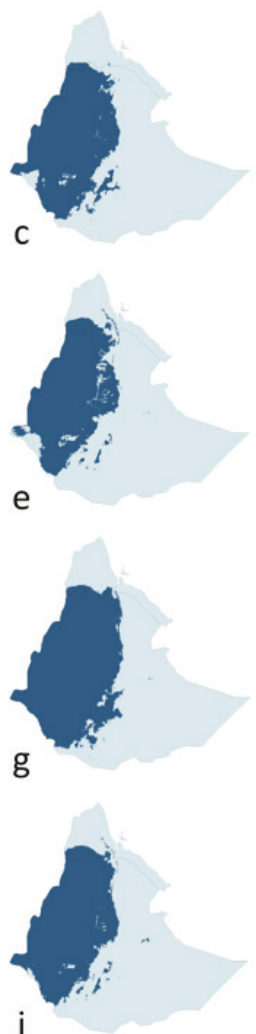

Image 3. Binary models output by MaxEnt for the distribution of Stenocephalemys albipes: a-current | b-2041-2060 in SSP2-4.5 and CanESM5 | c-2041-2060 in SSP5-8.5 and CanESM5 | d-2061-2080 in SSP2-4.5 and CanESM5 | e-2061-2080 in SSP5-8.5 and CanESM5 | f-2041-2060 in SSP2-4.5 and MIROC-ES2L | g-2041-2060 in SSP5-8.5 and MIROC-ES2L | h-2061-2080 in SSP2-4.5 and MIROCES2L | i-2061-2080 in SSP5-8.5 and MIROC-ES2L. Areas in dark blue represent high climatic suitability (i.e., the fundamental niche).

Table 3. Values for $\mathrm{BIO} 2$ (Mean diurnal range) and $\mathrm{BIO} 4$ (Temperature seasonality), averaged across both GCMs, for each time period and scenario for both species, at areas of high climatic suitability. Future values for $\boldsymbol{M}$. awashensis are not given as it has $\mathbf{0}$ climatic suitability in all scenarios. Values are given as Mean \pm standard deviation.

\begin{tabular}{|c|c|c|c|}
\hline \multicolumn{5}{|c|}{ Stenocephalemys albipes } \\
\hline Scenario & Time Period & BIO2 & BIO4 \\
\hline- & Current & $14.901 \pm 1.556$ & $114.903 \pm 28.698$ \\
\hline SSP2-4.5 & $2041-2060$ & $14.137 \pm 1.139$ & $109.902 \pm 30.14$ \\
\hline SSP5-8.5 & $2041-2060$ & $109.902 \pm 30.14$ & $14.065 \pm 1.185$ \\
\hline SSP2-4.5 & $2041-2060$ & $14.065 \pm 1.185$ & $111.027 \pm 32.302$ \\
\hline SSP5-8.5 & $2041-2060$ & $111.027 \pm 32.302$ & $14 \pm 1.171$ \\
\hline SSP2-4.5 & $2061-2080$ & $14 \pm 1.171$ & $116.249 \pm 33.281$ \\
\hline SSP5-8.5 & $2061-2080$ & $116.249 \pm 33.281$ & $13.572 \pm 1.258$ \\
\hline SSP2-4.5 & $2061-2080$ & $13.572 \pm 1.258$ & $123.561 \pm 39.416$ \\
\hline SSP5-8.5 & $2061-2080$ & $123.561 \pm 39.416$ & $14.935 \pm 1.318$ \\
\hline \multicolumn{5}{|c|}{ Mastomys awashensis } \\
\hline Scenario & Time Period & BIO2 & BIO4 \\
\hline- & Current & $15.986 \pm 1.075$ & $136.481 \pm 33.077$ \\
\hline
\end{tabular}
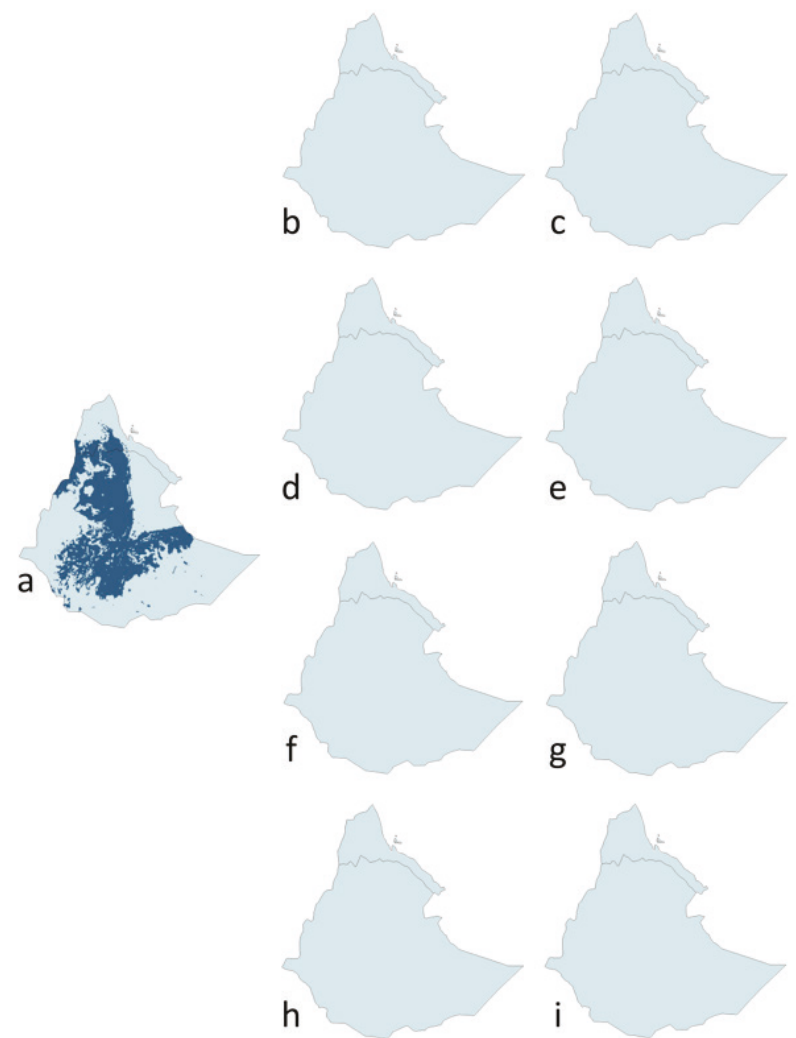

g
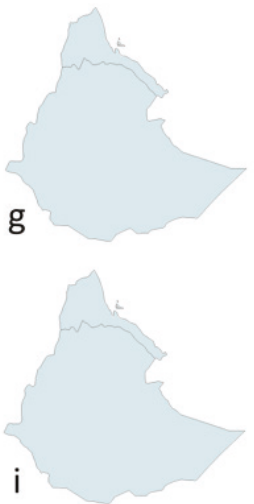

Image 4. Binary models output by MaxEnt for the distribution of Mastomys awashensis: a-current | b-2041-2060 in SSP2-4.5 and CanESM5 | c-2041-2060 in SSP5-8.5 and CanESM5 | d-2061-2080 in SSP2-4.5 and CanESM5 | e-2061-2080 in SSP5-8.5 and CanESM5 | f-2041-2060 in SSP2-4.5 and MIROC-ES2L | g-2041-2060 in SSP5-8.5 and MIROC-ES2L | h-2061-2080 in SSP2-4.5 and MIROCES2L | i-2061-2080 in SSP5-8.5 and MIROC-ES2L. Areas in dark blue represent high climatic suitability (i.e., the fundamental niche).

GCMs however, there was complete and total decline, resulting in $0 \%$ of the study area being climatically suitable by 2041-2060 and into the future (Image 4). This indicates that $M$. awashensis is extremely sensitive to climate change scenarios, and due to the effect of climate change alone, will lose all of its fundamental niche in the near future.

For this species, temperature seasonality (BIO4; $47.6 \%$ contribution, $74.2 \%$ p. imp.) and mean diurnal range (BIO2; $27.7 \%$ contribution, $18.2 \%$ p. imp.) were the highest contributors (Table 1 ). All the other variables had significantly lower percentage contribution and permutation importance.

In the current scenario, highest environmental suitability (>75\%) according to climate was seen at a mean diurnal range (BIO2) of $15.986 \pm 1.075{ }^{\circ} \mathrm{C}$, and a mean temperature seasonality (BIO4) of $136.481 \pm$ $33.077^{\circ} \mathrm{C}$ (Table 3). 


\section{DISCUSSION}

Ecological niche models have often been used to model and project rodent distributions and niches, but a large proportion of these studies are restricted to species found in the Americas (Martínez-Salazar et al. 2012; Bean et al. 2014; Kubiak et al. 2017; FloresZamarripa \& Fernández 2018; Urbina-Cardona et al. 2019; Pardi et al. 2020). African rodents have also been studied using ENM techniques; Taylor et al. (2015) showed that trends in the distribution of Afromontane rodents reflect changes in biomes predicted by past, present, and future climate scenarios. McDonough et al. (2015) showed in a hindcasting-based study on the Bushveld Gerbil Gerbiscillus leucogaster in Zambezi, that it is significantly impacted by changing climatic scenarios, but this was not explored in terms of future climate change. A general ecological niche model fitted by Martinov et al. (2020) created an estimation of the current predicted distribution of Mastomys species, including $M$. awashensis, however this analysis did not estimate the fundamental niche through binary modelling, and there was no projection to future climate scenarios.

Our results are in agreement with the findings of Martinov et al. (2020), where the current distributions show high likelihood $(>0.8)$ in areas included under our predicted current fundamental niche. Our results also emphasise the importance of ecological niche modelling and future projection of ENM analyses, due to the severity of the impact of climate change on $M$. awashensis (Ortega-Huerta \& Peterson 2008).

The two species in our study-Mastomys awashensis and Stenocephalemys albipes-show significant changes as a result of changing climate scenarios. The result of our study for $S$. albipes shows a percentage area of current climatic suitability of $20.704 \%$, with an increase of $18.437 \%$ in the near future (2041-2060), and a further increase of $1.373 \%$ in the distant future (20612080 ) in both climatic scenarios. Despite the different perspectives SSP2-4.5 and SSP5-8.5 take in terms of socioeconomic scenarios, emissions, and concentrations of greenhouse gases, there was negligible difference between the two in the future predictions of the fundamental niche of this species, suggesting that while climate change positively impacts this species, there is little impact of specific climate pathways. This result is in line with conclusions drawn by McDonough et al. (2015), where it was shown that rodent niches expanded from the last glacial maximum (approximately 200,000 years BP) through the last interglacial period (approx. 130,000 to 118,000 years BP), to the present day, most likely due to increasing temperatures across the year. The decrease in predicted future mean diurnal range most suitable for this species when compared to the current time period shows that in both shared socioeconomic pathway scenarios, this species will favour slightly colder climates. This effect is very small, however,as the largest change in mean diurnal range is from current to the 2061-2080 time period, with a $1.329 \pm 0.298{ }^{\circ} \mathrm{C}$ decrease.

In the case of $M$. awashensis, the current niche is relatively large, with $46.077 \%$ appearing to be climatically suitable for this species; however, it appears to be incredibly sensitive to climate change events, as in all future scenarios and time periods, none of the study area (and also the rest of Africa) appeared to be climatically suitable. This is a massive and drastic change, which reflects the high sensitivity of this species to climate change. Seasonal variation in temperature and mean diurnal range of temperature are the most important predicting factors for this species, which leads to the inference that this species is likely to be most affected by temperatures getting generally warmer and less seasonally varied, which happens in both scenarios.

According to the MaxEnt model, both species had relatively wide areas of climatic suitability (Imgae 3,4$)$. For both species, the northern regions of Ethiopia and parts of southern Eritrea were climatically suitable-this included highland, some lowland regions of the Great Rift Valley, and some scattered sites in southeastern Ethiopia. S. albipes had climatically suitable regions in the highlands of northern, western, and central Ethiopia, including Tigray, Amhara, northern Oromia, Southern Nations, Nationalities, \& Peoples' (SNNP), Addis Ababa, and eastern Benishangul-Gumaz regions. There are also some scattered suitable sites near Harari in Ethiopia, and Debub and Gash-Barka regions in Eritrea. In all future scenarios and time periods, this species' fundamental niche was seen to expand and move westward in Ethiopia and Eritrea, occupying the Tigray, Amhara, Benishangul-Gumaz, Oromia, Addis Ababa, Gambela, and SNNP regions in Ethiopia \& Gash-Barka and Debub regions in Eritrea. Some scattered areas of suitability were also seen in the Eritrean \& Ethiopian highlands and in the highlands south of Dire Dawa.

M. awashensis showed climatic suitability in Tigray, Amhara, eastern Benishangul-Gumaz, Oromia, SNNP, Addis Ababa, Harari, and some parts of northern Somali regions. In Eritrea, it showed high climatic suitability in Gash-Barka and Debub. For both species, the Eritrean and Ethiopian highlands formed a distinct geographical 
barrier, and no areas of climatic suitability were present east of the hill range. Earlier studies of both species have shown them to be restricted to highland habitats (Corti et al. 2005; Mohammed et al. 2010; Meheretu et al. 2014), however, some later studies reported them to occur from lowlands as well (Habtamu \& Bekele 2008; Lavrenchenko et al. 2010). Our study corroborates these with our current predicted niche expanding to lowland regions as well as highlands.

The results of the present study show the efficacy of ecological niche modelling in offering important insights into the potential geographic distributions of African rodents. Although $M$. awashensis is present and has areas of climatic suitability in protected areas, it is likely that there are no species-specific conservation measures in place. The eventual increase in anthropogenic impact on the natural areas will only decrease the chances of the species' survival in the future, as the impact of climate change alone is very large. It is important to plan groundtruthing of the sites shown as part of the fundamental niche of both this study's species in order to ascertain their true distribution, range, and realised niche, as this will help create better conservation strategies. It is imperative that species-specific conservation measures are set in place based on the results of said groundtruthing, including in situ conservation management, captive breeding, and planned reintroductions.

\section{REFERENCES}

Assefa, A. \& C. Srinivasulu (2019). Comparison of rodent community between natural and modified habitats in Kafta-Sheraro National Park and its adjoining villages, Ethiopia: implication for conservation. Journal of Basic and Applied Zoology 80, Article number: 59. https:// doi.org/10.1186/s41936-019-0128-9

Aiello-Lammens, M.E., R.A. Boria, A. Radosavljevic, B. Vilela \& R.P. Anderson (2015). spThin: an R package for spatial thinning of species occurrence records for use in ecological niche models. Ecography 38(5): 541-545. https://doi.org/10.1111/ecog.01132

Bean, W.T., L.R. Prugh, R. Stafford, H.S. Butterfield, M. Westphal \& J.S. Brashares (2014). Species distribution models of an endangered rodent offer conflicting measures of habitat quality at multiple scales. Journal of Applied Ecology 51(4): 1116-1125. https://doi. org/10.1111/1365-2664.12281

Cameron, G.N. \& D. Scheel (2001). Getting Warmer: Effect of Global Climate Change on Distribution of Rodents in Texas. Journal of Mammalogy 82(3): 652-680. https://doi.org/10.1644/15451542(2001)082<0652:GWEOGC>2.0.CO;2

Corti, M., R. Castiglia, P. Colangelo, E. Capanna, F. Beolchini, A. Bekele, N. Oguge, R. Makundi, S. Sichilima, H. Leirs, V. Verheyen, V. \& R. Verhagen (2005). Cytotaxonomy of rodent species from Ethiopia, Kenya, Tanzania and Zambia. Belgian Journal of Zoology 135: 197-216.

Elith, J., C.H. Graham, R.P. Anderson, M. Dudík, S. Ferrier, A. Guisan, R.J. Hijmans, F. Huettmann, J.R. Leathwick, A. Lehmann, J. Li, L.G. Lohmann, B.A. Loiselle, G. Manion, C. Moritz, M. Nakamura, Y. Nakazawa, J.M.M. Overton, A.T. Peterson, S.J. Phillips, K.
Richardson, R. Scachetti-Pereira, R.E. Schapire, J. Soberón, S. Williams, M.S. Wisz \& N.E. Zimmermann (2006). Novel methods improve prediction of species' distributions from occurrence data. Ecography 29(2): 129-151. https://doi.org/10.1111/j.2006.09067590.04596.x

Evans, J.S. (2020). spatialEco [R package] (Version 1.3-1)

Feng, X., D.S. Park, C. Walker, A.T. Peterson, C. Merow \& M. Papeş (2019). A checklist for maximizing reproducibility of ecological niche models. Nature Ecology \& Evolution 3(10): 1382-1395. https://doi. org/10.1038/s41559-019-0972-5

Fick, S.E. \& R.J. Hijmans (2017). WorldClim 2: new 1-km spatial resolution climate surfaces for global land areas. International Journal of Climatology 37(12): 4302-4315. https://doi.org/10.1002/ joc.5086

Fischer, C., C. Gayer, K. Kurucz, F. Riesch, T. Tscharntke \& P. Batáry (2018). Ecosystem services and disservices provided by small rodents in arable fields: Effects of local and landscape management. Journal of Applied Ecology 55(2): 548-558. https://doi.org/10.1111/13652664.13016

Flores-Zamarripa, F.J. \& J.A. Fernández (2018). Predictive species distribution model of two endemic kangaroo rats from Mexico: Dipodomys ornatus and D. phillipsii (Rodentia: Heteromyidae). Therya 9(3): 237-246. https://doi.org/10.12933/therya-18-605

Fricko, O., P. Havlik, J. Rogelj, Z. Klimont, M. Gusti, N. Johnson, P. Kolp, M. Strubegger, H. Valin, M. Amann, T. Ermolieva, N. Forsell, M. Herrero, C. Heyes, G. Kindermann, V. Krey, D.L. McCollum, M. Obersteiner, S. Pachauri, S. Rao, E. Schmid, W. Schoepp \& K. Riahi (2017). The marker quantification of the Shared Socioeconomic Pathway 2: A middle-of-the-road scenario for the $21^{\text {st }}$ century. Global Environmental Change 42: 251-267. https://doi.org/10.1016/j. gloenvcha.2016.06.004

Habtamu, T. \& A. Bekele (2008). Habitat association of insectivores and rodents of Alatish National Park, northwestern Ethiopia. Tropical Ecology 49(1): 1-11.

Happold, D.C.D. \& J. Kingdon (eds.) (2013). Mammals of Africa. Vol. 3: Rodents, Hares and Rabbits. Bloomsbury, London, 784pp.

Hutchinson, G.E. (1957). Concluding Remarks. Cold Spring Harbor Symposia on Quantitative Biology 22(0): 415-427. https://doi. org/10.1101/SQB.1957.022.01.039

Kassa, D. \& A. Bekele (2008). Species composition, abundance, distribution and habitat association of rodents of Wondo Genet, Ethiopia. SINET: Ethiopian Journal of Science 31(2): 141-146. https://doi.org/10.4314/sinet.v31i2.66637

Kasso, M., A. Bekele \& G. Hemson (2010). Species composition, abundance and habitat association of rodents and insectivores from Chilalo-Galama Mountain range, Arsi, Ethiopia: Small mammals of Chilalo-Galama Mountains. African Journal of Ecology 48(4): 11051114. https://doi.org/10.1111/j.1365-2028.2010.01222.x

Keller, E.F. \& E.A. Lloyd (eds.) (1999). Keywords in Evolutionary Biology. Harvard University Press, Cambridge, Mass., 414pp.

Kingdon, J. (1997). The Kingdon Field Guide to African Mammals. Academic Press, San Diego, London, Boston, 459pp.

Kriegler, E., N. Bauer, A. Popp, F. Humpenöder, M. Leimbach, J. Strefler, L. Baumstark, B.L. Bodirsky, J. Hilaire, D. Klein, I. Mouratiadou, I. Weindl, C. Bertram, J.-P. Dietrich, G. Luderer, M. Pehl, R. Pietzcker, F. Piontek, H. Lotze-Campen, A. Biewald, M. Bonsch, A. Giannousakis, U. Kreidenweis, C. Müller, S. Rolinski, A. Schultes, J. Schwanitz, M. Stevanovic, K. Calvin, J. Emmerling, S. Fujimori, S. \& O. Edenhofer (2017). Fossil-fueled development (SSP5): An energy and resource intensive scenario for the $21^{\text {st }}$ century. Global Environmental Change 42: 297-315. https://doi. org/10.1016/j.gloenvcha.2016.05.015

Kubiak, B.B., E.E. Gutiérrez, D. Galiano, R. Maestri \& T.R.O. de Freitas (2017). Can niche modeling and geometric morphometrics document competitive exclusion in a pair of subterranean rodents (Genus Ctenomys) with tiny parapatric distributions? Scientific Reports 7(1): 1-13. https://doi.org/10.1038/s41598-017-16243-2

Lavrenchenko, L.A., O.P. Likhnova, M.I. Baskevich \& A. Bekele (1998). Systematics and distribution of Mastomys (Muridae, Rodentia) 
from Ethiopia, with the description of a new species. Zeitschrift Für Säugetierkunde 63: 37-51.

Leroy, B., C.N. Meynard, C. Bellard \& F. Courchamp (2016). Virtualspecies, an $\mathrm{R}$ package to generate virtual species distributions. Ecography 39(6): 599-607. https://doi.org/10.1111/ecog.01388

Martínez-Salazar, E.A., T. Escalante, M. Linaje \& J. Falcón-Ordaz (2013). Predicting the potential distribution of Vexillata (Nematoda: Ornithostrongylidae) and its hosts (Mammalia: Rodentia) within America. Journal of Helminthology 87(4): 400-408. https://doi. org/10.1017/S0022149X12000612

Martynov, A.A., J. Bryja, Y. Meheretu \& L.A. Lavrenchenko (2020). Multimammate mice of the genus Mastomys (Rodentia: Muridae) in Ethiopia - diversity and distribution assessed by genetic approaches and environmental niche modelling. Journal of Vertebrate Biology 69(2): 1-16. https://doi.org/10.25225/jvb.20006

McDonough, M.M., R. Šumbera, V. Mazoch, A.M. Ferguson, C.D. Phillips \& J. Bryja (2015). Multilocus phylogeography of a widespread savanna-woodland-adapted rodent reveals the influence of Pleistocene geomorphology and climate change in Africa's Zambezi region. Molecular Ecology 24(20): 5248-5266. https://doi.org/10.1111/mec.13374

Meheretu, Y., V. Sluydts, K. Welegerima, H. Bauer, M. Teferi, G. Yirga, L. Mulungu, M. Haile, J. Nyssen, J. Deckers, R. Makundi \& H. Leirs (2014). Rodent abundance, stone bund density and its effects on crop damage in the Tigray highlands, Ethiopia. Crop Protection 55: 61-67. https://doi.org/10.1016/j.cropro.2013.10.016

Merow, C., M.J. Smith \& J.A. Silander (2013). A practical guide to MaxEnt for modeling species' distributions: what it does, and why inputs and settings matter. Ecography 36(10): 1058-1069. https:// doi.org/10.1111/j.1600-0587.2013.07872.x

Millien, V. \& J. Damuth (2004). Climate change and size evolution in an island rodent species: new perspectives on the island rule. Evolution 58(6): 1353. https://doi.org/10.1554/03-727

Monadjem, A. (2015). Rodents of Sub-Saharan Africa: A Biogeographic and Taxonomic Synthesis. Walter de Gruyter GmbH \& Co. KG, Berlin, Boston, 1,092pp

Muscarella, R., P.J. Galante, M. Soley-Guardia, R.A. Boria, J.M. Kass, M. Uriarte \& R.P. Anderson (2014). ENMeval: An R package for conducting spatially independent evaluations and estimating optimal model complexity for MaxEnt ecological niche models. Methods in Ecology and Evolution 5(11): 1198-1205. https://doi. org/10.1111/2041-210X.12261

Nowak, R.M. (1999). Walker's Mammals of the World, 6th edition. The Johns Hopkins University Press, Baltimore, 2pp.

Ortega-Huerta, M.A. \& A.T. Peterson (2008). Modeling ecological niches and predicting geographic distributions: a test of six presenceonly methods. Revista Mexicana de Biodiversidad 79: 205-216.

Pardi, M.I., R.C. Terry, E.A. Rickart \& R.J. Rowe (2020). Testing climate tracking of montane rodent distributions over the past century within the Great Basin ecoregion. Global Ecology and Conservation 24: e01238. https://doi.org/10.1016/j.gecco.2020.e01238

Phillips, S.J., R.P. Anderson \& R.E. Schapire (2006). Maximum entropy modeling of species geographic distributions. Ecological Modelling 190(3-4): 231-259. https://doi.org/10.1016/j. ecolmodel.2005.03.026

Porfirio, L. L., R.M.B. Harris, E.C. Lefroy, S. Hugh, S.F. Gould, G. Lee, N.L. Bindoff \& B. Mackey (2014). Improving the Use of Species Distribution Models in Conservation Planning and Management under Climate Change. PLOS ONE 9(11): e113749. https://doi. org/10.1371/journal.pone.0113749

R Core Team (2020). R: A language and environment for statistical computing. (Version 4.0.1). R Foundation for Statistical Computing, Vienna, Austria.
Radosavljevic, A. \& R.P. Anderson (2014). Making better Maxent models of species distributions: complexity, overfitting and evaluation. Journal of Biogeography 41(4): 629-643. https://doi. org/10.1111/jbi.12227

Royer, A., S. Montuire, S. Legendre, E. Discamps, M. Jeannet \& C. Lécuyer (2016). Investigating the Influence of Climate Changes on Rodent Communities at a Regional-Scale (MIS 1-3, Southwestern France). PLOS ONE 11(1): e0145600. https://doi.org/10.1371/ journal.pone.0145600

Soberón, J. \& B. Arroyo-Peña (2017). Are fundamental niches larger than the realized? Testing a 50 -year-old prediction by Hutchinson. PLOS ONE 12(4): e0175138. https://doi.org/10.1371/journal. pone.0175138

Swart, N.C., J.N.S. Cole, V.V. Kharin, M. Lazare, J.F. Scinocca, N.P. Gillett, J. Anstey, V. Arora, J.R. Christian, Y. Jiao, W.G. Lee, F. Majaess, O.A. Saenko, C. Seiler, C. Seinen, A. Shao, L. Solheim, K. von Salzen, D. Yang, B. Winter \& M. Sigmond (2019a). CCCma CanESM5 model output prepared for CMIP6 C4MIP esm-ssp585. Earth System Grid Federation. https://doi.org/10.22033/ESGF/CMIP6.10242

Swart, N.C., J.N.S. Cole, V.V. Kharin, M. Lazare, J.F. Scinocca, N.P. Gillett, J. Anstey, V. Arora, J.R. Christian, Y. Jiao, W.G. Lee, F. Majaess, O.A. Saenko, C. Seiler, C. Seinen, A. Shao, L. Solheim, K. von Salzen, D. Yang, B. Winter \& M. Sigmond (2019b). CCCma CanESM5 model output prepared for CMIP6 DAMIP ssp245-GHG. Earth System Grid Federation. https://doi.org/10.22033/ESGF/CMIP6.3686

Szpunar, G., G. Aloise, S. Mazzotti, L. Nieder \& M. Cristaldi (2008). Effects of global climate change on terrestrial small mammal communities in Italy. Fresenius Environmental Bulletin 17(9b): 1526-1533.

Tachiiri, K., M. Abe, T. Hajima, O. Arakawa, T. Suzuki, Y. Komuro, K. Ogochi, M. Watanabe, A. Yamamoto, H. Tatebe, M.A. Noguchi, R. Ohgaito, A. Ito, D. Yamazaki, A. Ito, K. Takata, S. Watanabe \& M. Kawamiya (2019a). MIROC MIROC-ES2L model output prepared for CMIP6 ScenarioMIP ssp245. Earth System Grid Federation. https:// doi.org/10.22033/ESGF/CMIP6.5745

Tachiiri, K., M. Abe, T. Hajima, O. Arakawa, T. Suzuki, Y. Komuro, K. Ogochi, M. Watanabe, A. Yamamoto, H. Tatebe, M.A. Noguchi, R. Ohgaito, A. Ito, D. Yamazaki, A. Ito, K. Takata, S. Watanabe \& M. Kawamiya (2019b). MIROC MIROC-ES2L model output prepared for CMIP6 ScenarioMIP ssp585. Earth System Grid Federation. https:// doi.org/10.22033/ESGF/CMIP6.5770

Takele, S., A. Bekele, G. Belay \& M. Balakrishnan (2011). A comparison of rodent and insectivore communities between sugarcane plantation and natural habitat in Ethiopia. Tropical Ecology 52(1): 61-68.

Taylor, P.J., A. Nengovhela, J. Linden \& R.M. Baxter (2016). Past, present, and future distribution of Afromontane rodents (Muridae: Otomys) reflect climate-change predicted biome changes. Mammalia 80(4): 359-375. https://doi.org/10.1515/ mammalia-2015-0033

Tilaye, W. (2005). Reproductive rhythm of the Grass Rat Arvicanthis abyssinicus at the Entoto Mountain, Ethiopia. Belgian Journal of Zoology 135: 53-56.

Urbina-Cardona, N., M.E. Blair, M.C. Londoño, R. Loyola, J. Velásquez-Tibatá \& H. Morales-Devia (2019). Species Distribution Modeling in Latin America: A 25-Year Retrospective Review. Tropical Conservation Science 12: 194008291985405. https://doi. org/10.1177/1940082919854058

Yalden, D.W. \& M.J. Largen (1992). The endemic mammals of Ethiopia. Mammal Review 22(3-4): 115-150. https://doi. org/10.1111/j.1365-2907.1992.tb00128.x

Zhang, Y., Z. Zhang \& J. Liu (2003). Burrowing rodents as ecosystem engineers: the ecology and management of Plateau Zokors Myospalax fontanierii in alpine meadow ecosystems on the Tibetan Plateau. Mammal Review 33(3-4): 284-294. https://doi. org/10.1046/j.1365-2907.2003.00020.x 
Appendix 1. Localities used in ENM analysis of Stenocephalemys albipes and Mastomys awashensis.

\begin{tabular}{|c|c|c|c|c|}
\hline Name & Latitude & Longitude & Locality & Reference \\
\hline Stenocephalemys albipes & 5.800 & 39.200 & Kebre Mengist, Ethiopia & GBIF \\
\hline Stenocephalemys albipes & 6.217 & 37.667 & Dega Done, Gemu-Gofa, SNNP, Ethiopia & Demeke et al. 2007 \\
\hline Stenocephalemys albipes & 6.233 & 37.567 & Mt Dorse, Chenckia, Gemu-Gofa, SNNP, Ethiopia & GBIF \\
\hline Stenocephalemys albipes & 6.383 & 38.583 & Kebre Mengist, Sidamo, Ethiopia & GBIF \\
\hline Stenocephalemys albipes & 6.833 & 40.550 & Jebo Samo, Bale, Ethiopia & GBIF \\
\hline Stenocephalemys albipes & 6.917 & 39.167 & Gedeb Mts., Ethiopia & GBIF \\
\hline Stenocephalemys albipes & 6.983 & 40.020 & $7 \mathrm{~km} \mathrm{SE}$ of Goba, Bale, Ethiopia & GBIF \\
\hline Stenocephalemys albipes & 7.050 & 39.167 & Webi river, north of Dodola, Arsi, Ethiopia & GBIF \\
\hline Stenocephalemys albipes & 7.100 & 39.767 & Webi river, $W$ of Dinshu, Bale, Ethiopia & Zerihun et al. 2012 \\
\hline Stenocephalemys albipes & 7.117 & 39.733 & $5 \mathrm{~km}$ of $\mathrm{W}$ of Dinshu, Bale, Ethiopia & GBIF \\
\hline Stenocephalemys albipes & 7.133 & 39.717 & Mount Gaysay, Bale, Ethiopia & GBIF \\
\hline Stenocephalemys albipes & 7.134 & 36.954 & Gorka Bersa, Chebera-Churchura NP, Ethiopia & Demeke \& Afework 2014 \\
\hline Stenocephalemys albipes & 7.433 & 35.000 & Godare forest, Tepi, Ethiopia & Lavrenchenko 2017 \\
\hline Stenocephalemys albipes & 7.580 & 36.800 & Seka, 3 Km N Of, Horo, Ethiopia & GBIF \\
\hline Stenocephalemys albipes & 7.600 & 38.450 & Alage, Ethiopia & Agerie \& Afework 2015 \\
\hline Stenocephalemys albipes & 7.620 & 36.770 & Buyo Kechema, Ethiopia & GBIF \\
\hline Stenocephalemys albipes & 7.650 & 36.800 & Jiren Farm, Jimma, Ethiopia & Tadesse \& Afework 2012 \\
\hline Stenocephalemys albipes & 7.667 & 39.333 & Albasso forest, Ethiopia & GBIF \\
\hline Stenocephalemys albipes & 7.750 & 36.730 & Atro, Agaro, Ethiopia & GBIF \\
\hline Stenocephalemys albipes & 7.820 & 36.680 & Agaro, $14 \mathrm{~km}$ by road SE of Mejo, Ethiopia & GBIF \\
\hline Stenocephalemys albipes & 7.833 & 39.333 & Wodajo, Ethiopia & GBIF \\
\hline Stenocephalemys albipes & 7.917 & 39.283 & Jawi Chilalo, Galama mtn, Arsi, Ethiopia & Mohammed et al. 2010 \\
\hline Stenocephalemys albipes & 7.917 & 39.450 & Mt Albasso, Camp Wodajo, Ethiopia & GBIF \\
\hline Stenocephalemys albipes & 8.155 & 35.525 & Illubabor, W of Gore, Ethiopia & GBIF \\
\hline Stenocephalemys albipes & 8.183 & 35.367 & Lemen, Ethiopia & GBIF \\
\hline Stenocephalemys albipes & 8.250 & 36.167 & Yemenigisit Den Yebaja Chaka, Ethiopia & GBIF \\
\hline Stenocephalemys albipes & 8.280 & 36.900 & Atenago, Ethiopia & GBIF \\
\hline Stenocephalemys albipes & 8.367 & 35.817 & Wabo, $5 \mathrm{~km}$ of W of Scecchi river, Ethiopia & GBIF \\
\hline Stenocephalemys albipes & 8.500 & 34.775 & Addo, $7 \mathrm{~km}$ SW of Dembidolo, Ethiopia & GBIF \\
\hline Stenocephalemys albipes & 8.517 & 39.200 & Wonji Sugarcane, Qoboluto Tumsa, Ethiopia & Serekebirhan et al. 2011 \\
\hline Stenocephalemys albipes & 8.917 & 38.583 & Dima Goranda, Ethiopia & GBIF \\
\hline Stenocephalemys albipes & 9.017 & 35.250 & Sido Were Wele, Ethiopia & GBIF \\
\hline Stenocephalemys albipes & 9.050 & 38.520 & Berifeta Lemefa, near Holetta, Ethiopia & GBIF \\
\hline Stenocephalemys albipes & 9.067 & 38.650 & Menagesha forest, Shoa, Ethiopia & Afework 1996 \\
\hline Stenocephalemys albipes & 9.117 & 37.050 & Bako, Shoa, Ethiopia & GBIF \\
\hline Stenocephalemys albipes & 9.517 & 38.217 & Subagajo, Ethiopia & GBIF \\
\hline Stenocephalemys albipes & 10.333 & 37.833 & Debra Markos, Gojjam, Amhara, Ethiopia & Ejigu \& Afework 2013 \\
\hline Stenocephalemys albipes & 10.494 & 39.611 & Yetere forest, Ethiopia & Gezahegn et al. 2016 \\
\hline Stenocephalemys albipes & 10.667 & 38.167 & Debre Werk, Ethiopia & GBIF \\
\hline Stenocephalemys albipes & 10.667 & 37.917 & Naziret M Alem, Ethiopia & GBIF \\
\hline Stenocephalemys albipes & 10.739 & 36.800 & Arditsy forest, Awi zone, Ethiopia & Getachew \& Afework 2015 \\
\hline Stenocephalemys albipes & 10.846 & 38.675 & Borena-Sayint NP, Ethiopia & Meseret \& Solomon 2014 \\
\hline Stenocephalemys albipes & 11.117 & 37.317 & Amedamit Mount, Amhara, Ethiopia & GBIF \\
\hline Stenocephalemys albipes & 11.167 & 36.250 & Pawe area, B. Gumuz, Ethiopia & Tilahun et al. 2012 \\
\hline
\end{tabular}




\begin{tabular}{|c|c|c|c|c|}
\hline Name & Latitude & Longitude & Locality & Reference \\
\hline Stenocephalemys albipes & 11.267 & 36.833 & Dangila, Amhara, Ethiopia & GBIF \\
\hline Stenocephalemys albipes & 11.417 & 37.967 & Shime, Ethiopia & GBIF \\
\hline Stenocephalemys albipes & 11.583 & 37.417 & Bihar-Dar, Amhara, Ethiopia & GBIF \\
\hline Stenocephalemys albipes & 11.717 & 37.917 & Mahdere Marayam, Gondar, Amhara, Ethiopia & GBIF \\
\hline Stenocephalemys albipes & 12.350 & 35.783 & Alatish NP, Ethiopia & Tadesse \& Afework 2008 \\
\hline Stenocephalemys albipes & 12.617 & 37.483 & Gondar, Amhara, Ethiopia & GBIF \\
\hline Stenocephalemys albipes & 12.633 & 37.500 & NE of Angereb Dam, Gondar, Amhara, Ethiopia & GBIF \\
\hline Stenocephalemys albipes & 12.750 & 37.700 & Yerer mountain forest, Shoa, Ethiopia & Yonas \& Fikresilasie 2015 \\
\hline Stenocephalemys albipes & 13.133 & 37.917 & Debark, NE Gondar, Amhara, Ethiopia & GBIF \\
\hline Stenocephalemys albipes & 13.133 & 37.917 & Semien Mts, Amhara, Ethiopia & GBIF \\
\hline Stenocephalemys albipes & 13.192 & 37.893 & Debir, Ethiopia & GBIF \\
\hline Stenocephalemys albipes & 13.232 & 38.038 & Semien NP, Ethiopia & GBIF \\
\hline Stenocephalemys albipes & 13.650 & 39.172 & Hagere-selam, Ethiopia & Meheretu et al. 2012 \\
\hline Stenocephalemys albipes & 14.166 & 37.309 & Habesha Adi Goshu, Ethiopia & GBIF \\
\hline Stenocephalemys albipes & 14.183 & 37.305 & Kunama Adi Goshe, Ethiopia & GBIF \\
\hline Stenocephalemys albipes & 14.210 & 36.766 & Adebayetown, Ethiopia & GBIF \\
\hline Stenocephalemys albipes & 14.251 & 37.270 & Kunama Adi Goshe, Ethiopia & GBIF \\
\hline Stenocephalemys albipes & 14.284 & 36.688 & Kafta-Sheraro NP, Tigray, Ethiopia & $\begin{array}{l}\text { Alembrhan \& Srinivasulu } \\
2019\end{array}$ \\
\hline Stenocephalemys albipes & 14.291 & 36.677 & Helet Coka, Ethiopia & GBIF \\
\hline Stenocephalemys albipes & 14.950 & 38.270 & Mt. Kullu, Shambiko, Eritrea & GBIF \\
\hline Stenocephalemys albipes & 15.332 & 39.064 & Nefasit, Eritrea & GBIF \\
\hline Stenocephalemys albipes & 11.083 & 36.850 & Aquatimo forest, Gojjam, Ethiopia & Moges \& Dessalegn 2015 \\
\hline Mastomys awashensis & 9.000 & 40.167 & Awash, Ethiopia & Lavrenchenko et al. 1998 \\
\hline Mastomys awashensis & 7.833 & 38.717 & S of Ziway Lake, Ethiopia & Corti et al. 2005 \\
\hline Mastomys awashensis & 8.383 & 39.150 & E of Koka Lake, Bati Qelo, Ethiopia & Lavrenchenko \& Corti 2008 \\
\hline Mastomys awashensis & 9.065 & 42.275 & Nigaya Bobasa, Babile Sanctuary, Ethiopia & Lavrenchenko et al. 2010 \\
\hline Mastomys awashensis & 13.668 & 39.175 & Hagere-selam, Ethiopia & Meheretu et al. 2014 \\
\hline Mastomys awashensis & 12.600 & 39.517 & $\mathrm{~N}$ of Lake Hashenge, Ethiopia & Mengistu et al. 2015 \\
\hline Mastomys awashensis & 14.210 & 36.766 & Near Adebaye Town, Kafta Sheraro National Park, Ethiopia & $\begin{array}{l}\text { Alembrhan \& Srinivasulu } \\
2019\end{array}$ \\
\hline Mastomys awashensis & 14.251 & 37.270 & Kunama Adi Goshu, Kafta Sheraro National Park, Ethiopia & $\begin{array}{l}\text { Alembrhan \& Srinivasulu } \\
2019\end{array}$ \\
\hline Mastomys awashensis & 14.284 & 36.688 & Helet Coka, Ethiopia & GBIF \\
\hline Mastomys awashensis & 14.287 & 36.679 & Adebaye Geter, E of Himora, Ethiopia & GBIF \\
\hline Mastomys awashensis & 14.184 & 37.305 & NW of Birkuta, Ethiopia & GBIF \\
\hline Mastomys awashensis & 14.168 & 37.310 & Habesha Adi Goshu, Ethiopia & GBIF \\
\hline Mastomys awashensis & 7.2545 & 36.798 & Gojeb River, Ethiopia & Martynov et al. 2020 \\
\hline Mastomys awashensis & 7.4782 & 36.5334 & Shebe, Ethiopia & Martynov et al. 2020 \\
\hline Mastomys awashensis & 8.2331 & 37.5887 & Gibe National Park, Ethiopia & Martynov et al. 2020 \\
\hline Mastomys awashensis & 8.2338 & 37.5823 & Gibe National Park, Ethiopia & Martynov et al. 2020 \\
\hline Mastomys awashensis & 8.4651 & 39.1606 & Lake Koka, Bati Qelo, Ethiopia & Martynov et al. 2020 \\
\hline Mastomys awashensis & 8.6943 & 36.4149 & Didessa River, Ethiopia & Martynov et al. 2020 \\
\hline Mastomys awashensis & 8.8453 & 40.0119 & Awash National Park, Ethiopia & Martynov et al. 2020 \\
\hline Mastomys awashensis & 9.0586 & 42.2796 & Babile Elephant Sanctuary, Ethiopia & Martynov et al. 2020 \\
\hline Mastomys awashensis & 9.1478 & 42.2624 & Babile Elephant Sanctuary, Ethiopia & Martynov et al. 2020 \\
\hline Mastomys awashensis & 9.2249 & 34.8662 & Dhati-Welel National Park, Ethiopia & Martynov et al. 2020 \\
\hline
\end{tabular}




\begin{tabular}{|l|c|c|l|l|}
\hline Name & Latitude & \multicolumn{1}{|l|}{ Longitude } & Locality & Reference \\
\hline Mastomys awashensis & 9.2393 & 34.8653 & Dhati-Welel National Park, Ethiopia & Martynov et al. 2020 \\
\hline Mastomys awashensis & 9.2449 & 34.8644 & Dhati-Welel National Park, Ethiopia & Martynov et al. 2020 \\
\hline Mastomys awashensis & 9.5548 & 39.7818 & Ankober, Ethiopia & Martynov et al. 2020 \\
\hline Mastomys awashensis & 9.5554 & 39.7657 & Ankober, Ethiopia & Martynov et al. 2020 \\
\hline Mastomys awashensis & 11.0526 & 39.6481 & Kombolcha, Ethiopia & Martynov et al. 2020 \\
\hline Mastomys awashensis & 11.7525 & 37.9068 & Gumara River, Ethiopia & Martynov et al. 2020 \\
\hline Mastomys awashensis & 11.7797 & 37.7313 & Gumara River, Ethiopia & Martynov et al. 2020 \\
\hline Mastomys awashensis & 12.5492 & 39.6431 & Adi Mancarre, Ethiopia & Martynov et al. 2020 \\
\hline Mastomys awashensis & 12.6393 & 39.5383 & Adi Aba Musa, Ethiopia & Martynov et al. 2020 \\
\hline Mastomys awashensis & 12.6551 & 39.5816 & Kube, Ethiopia & Martynov et al. 2020 \\
\hline Mastomys awashensis & 13.1858 & 37.9671 & Simien Mts National Park, Ethiopia & Martynov et al. 2020 \\
\hline Mastomys awashensis & 14.0945 & 37.4575 & Mai-Temen, Ethiopia & Martynov et al. 2020 \\
\hline
\end{tabular}




\begin{tabular}{|c|c|c|c|c|c|c|c|c|c|c|c|c|c|c|c|c|c|c|c|c|}
\hline$\frac{g}{0}$ & & & & & & & & & & & & & & & & & & & & 各 \\
\hline $\begin{array}{l}\infty \\
\stackrel{0}{0}\end{array}$ & & & & & & & & & & & & & & & & & & & & \\
\hline$\hat{0}$ & & & & & & & & & & & & & & & & & & & 会 & \begin{tabular}{|l}
\multirow{2}{*}{} \\
孛
\end{tabular} \\
\hline $\begin{array}{l}\frac{0}{\mathscr{O}} \\
\frac{\mathrm{O}}{\omega}\end{array}$ & & & & & & & & & & & & & & & & & 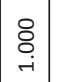 & 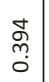 & 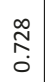 & 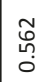 \\
\hline $\begin{array}{l}\frac{\mathscr{H}}{0} \\
\frac{\partial}{\infty}\end{array}$ & & & & & & & & & & & & & & & & & $\mid \begin{array}{l}2 \\
0 \\
0\end{array}$ & $\begin{array}{l}\infty \\
\underset{7}{\infty} \\
i \\
\vdots\end{array}$ & 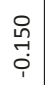 & 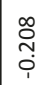 \\
\hline $\begin{array}{l} \pm \\
0\end{array}$ & & & & & & & & & & & & & & & 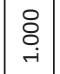 & 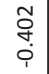 & $\mid \begin{array}{c}\tilde{N} \\
\tilde{m} \\
0\end{array}$ & $\begin{array}{c}\text { 总 } \\
\text { o. } \\
0\end{array}$ & $\begin{array}{l}0 \\
\substack{0 \\
0 \\
0}\end{array}$ & 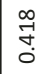 \\
\hline $\begin{array}{l}m \\
0 \\
\underline{0}\end{array}$ & & & & & & & & & & & & & & $\underset{i}{\stackrel{i}{~}}$ & 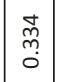 & $\begin{array}{l}\overrightarrow{a_{1}} \\
0\end{array}$ & $\mid \begin{array}{l}\vec{J} \\
\partial \\
0 \\
0\end{array}$ & $\begin{array}{c}\infty \\
\substack{0 \\
0 \\
0}\end{array}$ & $\begin{array}{l}\stackrel{n}{2} \\
0 \\
0\end{array}$ & 姜 \\
\hline$\frac{\tilde{O}}{\frac{O}{\infty}}$ & & & & & & & & & & & & & 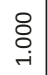 & 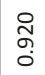 & $\begin{array}{c}\overrightarrow{1} \\
\hat{n} \\
0\end{array} \mid$ & 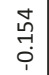 & $\left|\begin{array}{l}\hat{a} \\
o \\
o \\
0\end{array}\right|$ & 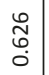 & 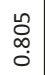 & $\begin{array}{l}\overrightarrow{\overrightarrow{0}} \\
\stackrel{0}{0}\end{array}$ \\
\hline$\stackrel{F}{\underline{O}}$ & & & & & & & & & & & & 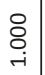 & 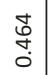 & స్ & $\begin{array}{l}\stackrel{0}{0} \\
\stackrel{0}{0} \\
0\end{array}$ & $\begin{array}{l}\text { m } \\
0 \\
0 \\
0\end{array}$ & $\mid$\begin{tabular}{l}
$\mathscr{2}$ \\
\multirow{2}{0}{} \\
0
\end{tabular} & 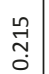 & $\begin{array}{l}\underset{N}{N} \\
\text { On }\end{array}$ & $\begin{array}{c}\infty \\
\tilde{m} \\
0 \\
0\end{array}$ \\
\hline $\begin{array}{l}\frac{O}{0} \\
\frac{0}{\infty}\end{array}$ & & & & & & & & & & & 8 & $\begin{array}{l}0 \\
\stackrel{0}{0} \\
\stackrel{0}{0}\end{array}$ & 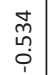 & $\begin{array}{l}\text { fo } \\
\text { fo }\end{array}$ & $\left|\begin{array}{c}m \\
0 \\
0 \\
i\end{array}\right|$ & $\begin{array}{l}0 \\
\stackrel{i}{1} \\
0\end{array}$ & $\left|\begin{array}{l}0 \\
f \\
0 \\
1\end{array}\right|$ & $\begin{array}{c}\stackrel{\sim}{2} \\
\stackrel{i}{i}\end{array}$ & $\begin{array}{l}\vec{n} \\
\hat{n} \\
\vdots \\
i\end{array}$ & 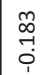 \\
\hline$\frac{\text { Oे }}{\infty}$ & & & & & & & & & & & 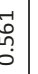 & 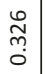 & $\begin{array}{l}\vec{H} \\
0 \\
0 \\
\dot{i}\end{array}$ & $\begin{array}{l}\text { 㟔 } \\
\text { ô }\end{array}$ & $\begin{array}{l}\tilde{\delta} \\
0 \\
i\end{array}$ & $\left|\begin{array}{l}0 \\
0 \\
0 \\
i\end{array}\right|$ & $\left|\begin{array}{l}n \\
0 \\
0 \\
0 \\
i\end{array}\right|$ & $\begin{array}{l}\hat{0} \\
0 \\
0\end{array}$ & 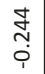 & $\mid \begin{array}{l}\infty \\
0 \\
0 \\
0 \\
0\end{array}$ \\
\hline $\begin{array}{l}\frac{\infty}{\omega} \\
\frac{0}{\infty}\end{array}$ & & & & & & & & \& & 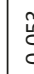 & 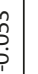 & 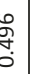 & $\begin{array}{l}\infty \\
\hat{n} \\
0 \\
0\end{array}$ & $\begin{array}{l}0 \\
0 \\
0 \\
0\end{array}$ & $\begin{array}{l}\text { õ } \\
\text { o. }\end{array}$ & $\left|\begin{array}{l}0 \\
o \\
0 \\
0\end{array}\right|$ & $\mid \begin{array}{l}\stackrel{g}{g} \\
\dot{g}\end{array}$ & $\left|\begin{array}{l}2 \\
0 \\
0 \\
0\end{array}\right|$ & $\begin{array}{c}\tilde{0} \\
0 \\
0 \\
0\end{array}$ & 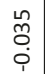 & \begin{tabular}{|l} 
\\
0 \\
0 \\
0
\end{tabular} \\
\hline$\frac{\hat{o}}{\infty}$ & & & & & & & ৪ & D & $\dot{c}$ & $\vec{b}$ & $\begin{array}{l}0 \\
0 \\
0 \\
0\end{array}$ & $\begin{array}{l}\mathscr{2} \\
0 \\
0 \\
0\end{array}$ & $\begin{array}{c}\stackrel{8}{\infty} \\
0 \\
0\end{array}$ & 孞 & $\mid \begin{array}{l}\vec{b} \\
0 \\
0\end{array}$ & $\left.\mid \begin{array}{l}n \\
0 \\
0 \\
0\end{array}\right]$ & 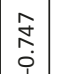 & 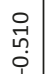 & $\begin{array}{l}n \\
0 \\
0 \\
0\end{array}$ & 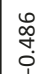 \\
\hline$\frac{\%}{\omega}$ & & & & & & ঃ & : & $\begin{array}{l}\infty \\
\stackrel{\infty}{\sigma} \\
0\end{array}$ & ત̃ & 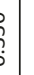 & $\begin{array}{l}\hat{a} \\
0 \\
0\end{array}$ & 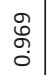 & 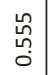 & \begin{tabular}{l}
\multirow{2}{*}{} \\
$\hat{n}$ \\
0
\end{tabular} & $\left|\begin{array}{c}0 \\
0 \\
0 \\
0\end{array}\right|$ & $\mid \begin{array}{c}\mathbb{1} \\
\stackrel{1}{0}\end{array}$ & $\mid \begin{array}{c}\text { g } \\
\text { ch }\end{array}$ & 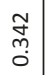 & $\begin{array}{c}0 \\
\substack{0 \\
0}\end{array}$ & \begin{tabular}{|l} 
do \\
ơ
\end{tabular} \\
\hline$\frac{\stackrel{\circ}{O}}{\omega}$ & & & & & \& & $\approx$ & $\mid \begin{array}{l}\infty \\
0 \\
0 \\
0\end{array}$ & 5 & 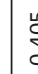 & $\begin{array}{l}b \\
⿱ \\
\vdots \\
b\end{array}$ & 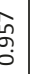 & $\begin{array}{l}\tilde{D} \\
\tilde{O} \\
0\end{array}$ & $\begin{array}{l}0 \\
\stackrel{0}{0} \\
i\end{array}$ & 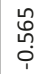 & $\left|\begin{array}{l}0 \\
⿱ 亠 \\
0 \\
i\end{array}\right|$ & 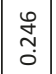 & $\left|\begin{array}{l}u \\
0 \\
0 \\
0 \\
i\end{array}\right|$ & $\begin{array}{l}0 \\
\tilde{q} \\
i \\
i\end{array}$ & $\begin{array}{c}\tilde{m} \\
0 \\
0 \\
\vdots\end{array}$ & $\mid \begin{array}{c}\infty \\
m \\
0 \\
i\end{array}$ \\
\hline$\frac{\mathrm{O}}{\omega}$ & & & & 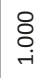 & \begin{tabular}{|l} 
\\
0 \\
0
\end{tabular} & o & $\begin{array}{l}\infty \\
\stackrel{\infty}{0} \\
\stackrel{2}{0}\end{array}$ & \begin{tabular}{l}
$\infty$ \\
\multirow{2}{*}{}
\end{tabular} & & & 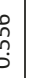 & 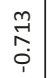 & $\begin{array}{l}0 \\
\hat{1} \\
i\end{array}$ & $\begin{array}{l}0 \\
\stackrel{0}{0} \\
i \\
i\end{array}$ & $\mid \begin{array}{c}\hat{1} \\
\hat{n} \\
i\end{array}$ & \begin{tabular}{c}
0 \\
0 \\
\hdashline \\
$i$ \\
$i$
\end{tabular} & $\left|\begin{array}{l}0 \\
\vdots \\
0 \\
i\end{array}\right|$ & 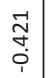 & $\begin{array}{l}\hat{\tilde{o}} \\
0 \\
0\end{array}$ & $\begin{array}{l}\vec{f} \\
i \\
i\end{array}$ \\
\hline$\frac{\tilde{O}}{\infty}$ & & & 8 & $\begin{array}{l}\overrightarrow{\hat{n}} \\
\text { } \\
\text { in }\end{array}$ & $\begin{array}{l}\text { to } \\
0 \\
\end{array}$ & $\stackrel{f}{ }$ & ஃ̆ & $\stackrel{m}{m}$ & 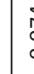 & & م. & $\begin{array}{l}\overrightarrow{0} \\
0 \\
0\end{array}$ & $\begin{array}{l}\hat{0} \\
0 \\
0\end{array}$ & 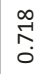 & $\mid \begin{array}{l}\mathscr{g} \\
\vdots \\
0 \\
0\end{array}$ & $\begin{array}{l}\tilde{O} \\
0 \\
0\end{array}$ & $\left|\begin{array}{l}0 \\
i \\
0\end{array}\right|$ & $\begin{array}{l}\hat{0} \\
0 \\
0\end{array}$ & $\begin{array}{l}0 \\
\stackrel{0}{0} \\
0 \\
0\end{array}$ & 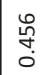 \\
\hline$\frac{\tilde{O}}{\infty}$ & & ঃ & 宛 & 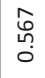 & 恙 & ֶ̊. & $\begin{array}{l}\mathscr{g} \\
\stackrel{2}{\Sigma}\end{array}$ & $\stackrel{\infty}{\beth}$ & & & $\begin{array}{l}\vec{y} \\
\vdots \\
0\end{array}$ & 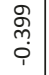 & $\begin{array}{l}\hat{0} \\
0 \\
i\end{array}$ & 怂 & $\mid$\begin{tabular}{l}
$\infty$ \\
\multirow{f}{0}{} \\
$i$
\end{tabular} & $\mid \begin{array}{c}\infty \\
\stackrel{\infty}{0} \\
0\end{array}$ & $\left|\begin{array}{l}-1 \\
0 \\
0 \\
0 \\
1\end{array}\right|$ & 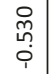 & 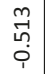 & \begin{tabular}{|l}
$\vec{q}$ \\
$\dot{q}$ \\
$i$ \\
$i$
\end{tabular} \\
\hline$\frac{\vec{O}}{\infty}$ & 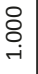 & ஜू & $\vec{J}$ & $\begin{array}{l}\text { 光 } \\
\text { in }\end{array}$ & \begin{tabular}{|l}
$\stackrel{m}{0}$ \\
0 \\
0
\end{tabular} & $\begin{array}{l}\overrightarrow{0} \\
\stackrel{0}{0}\end{array}$ & స్ & $\frac{\text { J }}{\partial}$ & 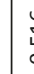 & & 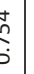 & 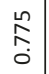 & $\begin{array}{l}\vec{H} \\
0 \\
0 \\
i\end{array}$ & I & $\left|\begin{array}{l}2 \\
\hat{0} \\
i \\
i\end{array}\right|$ & 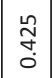 & $\mid \begin{array}{l}0 \\
0 \\
0\end{array}$ & $\begin{array}{l}\hat{a} \\
0 \\
0 \\
1\end{array}$ & 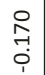 & \begin{tabular}{|l}
0 \\
0 \\
0 \\
0
\end{tabular} \\
\hline 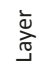 & $\frac{\mathrm{O}}{\mathrm{N}}$ & ธِ & $\underline{0}$ & $\frac{\mathrm{o}}{\mathrm{O}}$ & 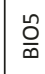 & ¿ & $\underline{\underline{\sigma}}$ & $g$ & & & $\frac{0}{0}$ & $\frac{\overrightarrow{0}}{\frac{0}{\infty}}$ & $\frac{\tilde{O}}{\infty}$ & $\frac{m}{\frac{0}{\infty}}$ & $\begin{array}{l}\vec{J} \\
\frac{\mathrm{O}}{\infty}\end{array}$ & $\begin{array}{l}\tilde{L} \\
\frac{0}{\infty} \\
0\end{array}$ & $\left|\begin{array}{l}\stackrel{0}{1} \\
\frac{0}{\infty}\end{array}\right|$ & $\frac{\vec{O}}{\infty}$ & $\begin{array}{l}\stackrel{\infty}{\square} \\
\stackrel{0}{\infty}\end{array}$ & $\underline{\underline{0}}$ \\
\hline
\end{tabular}





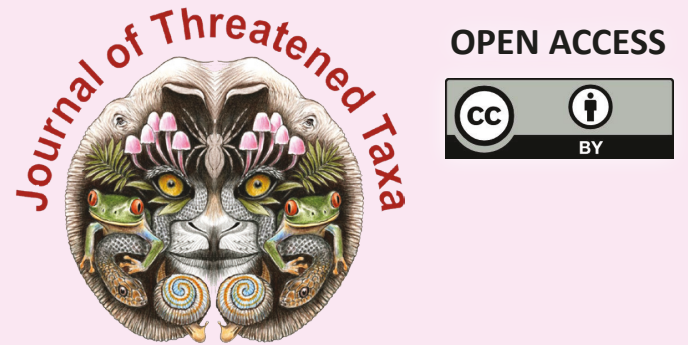

www.threatenedtaxa.org

The Journal of Threatened Taxa (JoTT) is dedicated to building evidence for conservation globally by publishing peer-reviewed articles online every month at a reasonably rapid rate at www.threatenedtaxa.org. All articles published in JoTT are registered under Creative Commons Attribution 4.0 International License unless otherwise mentioned. JoTT allows allows unrestricted use, reproduction, and distribution of articles in any medium by providing adequate credit to the author(s) and the source of publication.

\title{
ISSN 0974-7907 (Online) | ISSN $0974-7893$ (Print)
}

\author{
April 2021 | Vol. 13 | No. 5 | Pages: 18099-18410 \\ Date of Publication: 26 April 2021 (Online \& Print) \\ DOI: 10.11609/jott.2021.13.5.18099-18410
}

Articles

Spatiotemporal movement pattern of Asian Elephants Elephas maximus Linnaeus, 1758 in Sindhudurg District, Maharashtra, India

- Milind Digambar Patil, Vinayak Krishna Patil \& Ninad Avinash Mungi, Pp. 18099-18109

Conservation ecology of birds in Mt. Hilong-hilong, a Key Biodiversity Area on Mindanao Island, the Philippines

- Arturo G. Gracia Jr., Alma B. Mohagan, Janezel C. Burlat, Welfredo L. Yu Jr., Janine Mondalo, Florfe M. Acma, Hannah P. Lumista, Riah Calising \& Krizler Cejuela Tanalgo, Pp. 18110-18121

Nesting and hatching behaviour of Olive Ridley Turtles Lepidochelys olivacea (Eschscholtz, 1829) (Reptilia: Cryptodira: Cheloniidae) on Dr. Abdul Kalam Island, Odisha, India - P. Poornima, Pp. 18122-18131

\section{Communications}

Feeding ecology of Walia Ibex Capra walie (Mammalia: Artiodactyla: Bovidae) in Simien Mountains National Park, Ethiopia

- D. Ejigu, A. Bekele \& L. Powell, Pp. 18132-18140

Assessment of crop and property damage caused by Semnopithecus vetulus nestor (Bennett, 1833) (Mammalia: Primates: Cercopithecidae) in Gampaha District, Sri Lanka - Sunil Wijethilaka, Lakshani S. Weerasekara, Saumya Bandara \& Kithsiri B. Ranawana, Pp. 18141-18147

Habitat preference of the Indian Pangolin Manis crassicaudata inhabiting Margalla Hills National Park, Islamabad, Pakistan

- Tariq Mahmood, Shaista Andleeb \& Faraz Akrim, Pp. 18148-18155

The endangered Himalayan Red Panda: first photographic evidence from its westernmost distribution range

- Saroj Shrestha, Sony Lama, Ang Phuri Sherpa, Sonam Tashi Lama \& Dinesh Ghale, Pp. 18156-18163

Ecological niche modelling predicts significant impacts of future climate change on two endemic rodents in eastern Africa

- Aditya Srinivasulu, Alembrhan Assefa \& Chelmala Srinivasulu, Pp. 18164-18176

Avian diversity in a fragmented landscape of central Indian forests (Bhopal Forest Circle) - Amit Kumar, Yogesh Dubey \& Advait Edgaonkar, Pp. 18177-18188

Nest tree preference shown by Ring-necked Parakeet Psittacula krameri (Scopoli, 1769) in northern districts of Tamil Nadu, India

- M. Pandian, Pp. 18189-18199

Two new species of Euphaea Selys, 1840 (Odonata: Zygoptera: Euphaeidae) from northern Western Ghats, India

- Shriram Dinkar Bhakare, Vinayan P Nair, Pratima Ashok Pawar, Sunil Hanmant Bhoite \& Kalesh Sadasivan, Pp. 18200-18214

Two new light attracted rove beetle species of Astenus Dejean, 1833 (Coleoptera: Staphylinidae: Paederinae) from Kerala, India

- P. Sreevidhya, S.V. Akhil \& C.D. Sebastian, Pp. 18215-18226

A new distribution record of mason wasp Pison punctifrons Shuckard, 1838 (Hymenoptera: Sphecidae: Larrinae) from Noida, Uttar Pradesh, India

- Rajiv K. Singh Bais \& Aakash Singh Bais, Pp. 18227-18236

Diversity of freshwater molluscs from the upper Brahmaputra Basin,

Assam, India

- Jyotish Sonowal, Munmi Puzari \& Devid Kardong, Pp. 18237-18246

Diversity of understory flowering plants in the forest patches of Marilog District,

Philippines

- Florfe M. Acma, Noe P. Mendez, Noel E. Lagunday \& Victor B. Amoroso, Pp. 18247-18256

Legumes of Kerala, India: a checklist

- Anoop P. Balan \& S.V. Predeep, Pp. 18257-18282
Legumes (Angiosperms: Fabaceae) of Bagalkot District, Karnataka, India

- Jagdish Dalavi, Ramesh Pujar, Sharad Kambale, Varsha Jadhav-Rathod \& Shrirang Yadav, Pp. 18283-18296

Indigenous knowledge of ethnomedicinal plants by the Assamese community in Dibrugarh District, Assam, India

- Pranati Gogoi \& Namita Nath, Pp. 18297-18312

Short Communications

Marine mammal strandings in the northern Palk Bay from 2009 to 2020 - Vedharajan Balaji \& Veeramuthu Sekar, Pp. 18313-18318

First distribution record of the Asiatic Toad Bufo gargarizans Cantor, 1842 from India Dibang Valley in Arunachal Pradesh

- Sahil Nijhawan, Jayanta Kumar Roy, Iho Mitapo, Gata Miwu, Jibi Pulu \& M. Firoz Ahmed, Pp. 18319-18323

A checklist of fishes of Telangana State, India

- Kante Krishna Prasad \& Chelmala Srinivasulu, Pp. 18324-18343

Report on the stingless bees of Bhutan (Hymenoptera: Apidae: Meliponini) - Tshering Nidup, Pp. 18344-18348

New records of six termite (Blattodea: Termitidae) species from Kerala, India - Poovoli Amina \& K. Rajmohana, Pp. 18349-18354

Status, abundance, and seasonality of butterfly fauna at Kuvempu University Campus, Karnataka, India

- M.N. Harisha \& B.B. Hosetti, Pp. 18355-18363

Observations on butterflies of non-protected areas of Titabar, Assam, India - Abhijit Konwar \& Manashi Bortamuly, Pp. 18364-18377

Three new distribution records of Conidae (Gastropoda: Neogastropoda: Conoidea) from the Andaman Islands, India

- Jayaseelan Benjamin Franklin \& Deepak Arun Apte, Pp. 18378-18384

A new record of an endangered and endemic rare Rein Orchid Habenaria rariflora from Gujarat, India

- Mital R. Bhatt, Pp. 18385-18389

Glimpse of climber diversity in Saharanpur District, Uttar Pradesh, India - Lalita Saini, Archasvi Tyagi, Inam Mohammad \& Vijai Malik, Pp. 18390-18397

First report of the fleshy mushroom Trichaleurina javanica (Rehm) M. Carbone et al. (Ascomycota: Pezizales: Chorioactidaceae) from southern India - Munuswamy Kumar, Sekar Nithya \& Antony Agnes Kayalvizhi, Pp. 18398-18402

Notes

Photographic record of Temminck's Tragopan Tragopan temminckii (Gray, 1831) (Aves: Galliformes: Phasianidae) from eastern Bhutan: an evidence of its westward range expansion

- Tshering Dorji, Kinley Kinley, Letro Letro, Dawa Tshering \& Prem Nanda Maidali, Pp. 18403-18405

The Malay Cardamom Meistera aculeata (Roxb.) Škorničk. \& M.F. Newman (Zingiberaceae: Alpinioideae) from the Palghat gap: a new record to Kerala, India

- Vadakkeveedu Jagadesh Aswani, Manjakulam Khadhersha Jabeena \& Maya

Chandrashekaran Nair, Pp. 18406-18410

\section{Member}

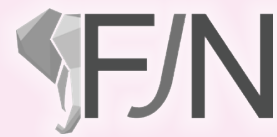

Publisher \& Host
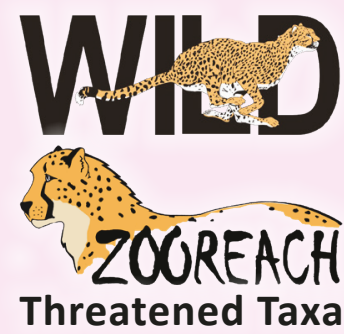